\title{
The Role of Technology in Development Policy in the Era of Globalization in South Sulawesi Indonesia
}

\author{
Andi Cudai Nur*, Risma Niswaty, Delly Mustafa, Muhammad Guntur, Aslinda \\ Universitas Negeri Makassar \\ Makassar, Indonesia \\ *cudainur@gmail.com, risma.niswaty@unm.ac.id, delly.mustafa0906@gmail.com,m.guntur@unm.ac.id, \\ aslinda110@yahoo.com
}

\begin{abstract}
This study tries to further look at how local governments use existing technology to develop regional development by creating a digitalization strategy. Local governments can take advantage of technology in development, by designing a policy digitalization strategy to support development excellence in tourism areas to realize competitive and sustainable development in South Sulawesi. This study uses a combination of sequential explanatory research models or design methods that combine a combination of quantitative and qualitative research methods in series, where in the first stage research is carried out using quantitative methods and in the second stage with qualitative methods. The development of tourism destinations, preferably from the initial process, needs to be supported by digitalization of technology and policies in the following aspects: 1) Cultural characteristics, historical conditions, cultural and social conditions that affect the process and outcome. 2) Administrative, legal and political framework, with various administrative provisions, laws and regulations, and political conditions for tourism development. 3) The level of integration of various stakeholders, including the implementation of the tourism business model. This study tries to further look at how local governments use existing technology to develop the tourism sector by designing a simple digitalization strategy.
\end{abstract}

Keywords-the role, policy, tecnonology, development, globalization

\section{INTRODUCTION}

Advances in science and technology have slowly changed the face of the world from conventional times to IT-based development (internet). In this change, of course, change the direction of some aspects of life, especially in Indonesia, where social, economic, and also educational aspects will adjust to these changes [1]. The development of science and technology is one sign of the entry of a new era for the world, the era of globalization, where a country is demanded to be more open to information or modernization that comes from outside if it does not want its country alienated from international relations. The main cause of this globalization era is due to the rapid development of information and communication technology that makes human life easier and more efficient.
The relevance of information technology affects development in Indonesia, can be seen from the seriousness of the government in realizing the relevance of information technology for development, by preparing six policies that can optimize the impact and results of the implementation of technological advances in Indonesia: 1) improve the quality of digital services to improve the efficiency and competitiveness of the sector which drives Indonesia's economic growth; 2) improve the quality of human resources to be able to adapt to future employment needs; 3) integrating research, design and development with the modernization of industry and other productive sectors; 4) encourage development to support economic growth by maximizing support for internet connectivity and mobile penetration; 5) strengthen the innovation ecosystem by collaborating with government, business people, educating national institutions, and the community; 6) encourage startup collaboration, including ecosystem development, acceleration, incubation to the business model and sustainable aspects of the startup business [2]. As a national planning agency, PPN/Bappenas relies on developing digital technology to improve the quality of development planning, which includes a digital transformation road map, harmonization of laws and regulations, fiscal policy, ease of doing business, and availability of access to funding and skilled labor. Indonesia carries out sustainable development in all sectors to support state revenue, one of which is through the development of the tourism sector. Today's tourism sector continues to grow in line with the increasing diversity of human needs and desires, these needs can be in the form of physical, psychological, and intellectual needs [3-7].

The role of the tourism sector as one of the main sectors in the national economy should be increased, with the hope to become one of the largest foreign exchange earners from intersector foreign exchange in Indonesia. In connection with this, a concept or formulation of a national tourism development plan (RIPPNAS), regional / provincial (RIPP-province), and local city (RIPP-district / city) is needed. The special level of government of Bulukumba, in the Tourism Development Master Plan (RIPP) is a translation from the RIPP of South Sulawesi Province. The development of the Bulukumba Master 
Plan Tourism Development in accordance with the diversity of destinations in this region has many potential tourism objects, however there is still a need for more optimal political attention and efforts from the Government of Bulukumba in increasing local revenue (PAD) originating from the tourism sector. At present, innovations in government institutions in Indonesia have been implemented, but have not been sufficient [8-13]. There are already many central and regional government institutions that have innovations in various fields of duties and functions, especially in providing public services to the public. There are several factors that can support the implementation of innovation, namely visionary leaders; open leadership; collaborative stakeholders; and community [14]. Related to this problem, several factors that influence in determining the sustainability of innovation in government institutions are the culture to provide feedback; accountability and continuous learning [15]. But the infrastructure has not been well managed and the level of security is still low [16]. Meanwhile, at the local government level, the results of the study indicate that local governments do not yet have strong leadership, clear master plans, and systematic readiness in directing the establishment of a standard e-Government system [17]. Travel is a community activity outside the residential area in a short time (less than one year) for the purpose of taking time [18-24]. Tourism trends which were initially dominated by conventional tourism are mass tourism which has more negative impacts [25-28]. There are complex relationships between elements in tourism, such as tourists, local governments, local communities, universities, educational communities and nongovernmental organizations $[4,5,29,30]$. Tourists are visitors who travel more than one night [31]. The WTO explains that non-permanent trips with the aim of leisure, picnics are also called vacation homes [31]. In essence tourists come for vacation $[4,5,29,30]$. Furthermore, ecotourism is one form of tourism that emphasizes the moral context as part of tourism [3,6,32]. Ecotourism is one part of the antithesis of mass tourism. In the context of tourism, special interests of tourists are invited to do something in the midst of a positive or enlightening vacation. It is in this special interest tour that the environmental order becomes part of the increase in resources [33]. In the current era of information technology, the role of new media-based tourism communication information media is very important. It is expected that easy access to information is the main asset as well as the tourism asset itself. Information is data provided in accordance with needs and goals [7,34].

Alvin Toffler in his book The Third Wave analyzes the changes and technological updates in the world. He divided the history of technology into 3 waves, namely [35]: (1) Century 800 BC-1700, or before the industrial revolution, (2) Th18001970, namely the period of the industrial revolution that began with the invention of the steam engine which eventually developed into high-level electronic technology, (3) Th19702000, marked by technological advances in the fields of: a) data communication and processing, b) aviation and aerospace technology applications. The main objective of developing digital technology is mutual assistance or complementarity between humans and machines through interaction [36,37].
Planning is also a political decision related to the work of the government as director and controller. Policies that guide the development of the tourism sector require regulations as a means of control, to determine the extent to which progress is expected. Whatever the life cycle level, the tourism area has its own level of development in 1) Cultural features, historical conditions, cultural and social conditions influence the process and outcome. 2) Administrative, legal and political frameworks, with various administrative provisions, rules and regulations, and the political conditions of tourism development. 3) The level of integration is the level of integration of various parties, including the application of the tourism business model. The level of the cycle must get the attention of local authorities to develop optimal efforts, especially the application of higher quality regulatory systems based on digital technology. The development of regional tourism, in this case Bulukumba is developing tourist destinations and tourism potential in this case: Tanjung Bira, Ammatoa Kajang and Pinishi Shipbuilding. These three attractions still maintain authenticity and natural conditions, all of them still exist and in traditional life systems that are rooted in the lives of local people. This is an attraction for tourists to visit the three destinations concerned, besides that Bulukumba is very strategic because the availability of potential tourism resources is very diverse, such as marine tourism / natural resources, natural, historical and cultural tourism as well as agro attractions. ODTW is very interesting, both for leisure activities, holidays, and as research activities. This study tries to see how local governments take the opportunity to develop the local tourism sector, by creating a deeper and comprehensive digitalization strategy to support the excellence of developing competitive tourism areas in South Sulawesi.

In this case, how to illustrate the natural charm of cultural and historical diversity in Bulukumba, starting from the beauty of the Tanjung Bira coast, the construction of the Phinisi ship, and the Ammatoa Indigenous area that is well known by the natives to foreign countries. All of this must be developed even better by applying modern digital technology systems to be effective and efficient. Good quality tourism planning and management needs to be improved to maintain the balance of the natural environment and the human environment (social and cultural) Understanding of this problem is needed at the regional and national level, with the provision of appropriate measures specifically at the local level, because local actions will be felt directly to have an impact on the solution of local problems.

There are several theories that support information and communication technology to realize development, human, economic and social: a) Factors affecting information systems include, among others, quantitative methods used, factors in the use of computers as assistive devices, human resource actors [38]. Technological progress in Indonesia has a different impact on urban and rural areas, for example a positive impact on the field of communication is that everyone can communicate smoothly and quickly without being hindered by time and distance [39]; b) The Characteristics of Technology according to their nature are divided into 3 types, by 
Djojohadikusumo [40], which can support the economy as follows: 1) Advanced technology, 2) Adaptive technology, 3. Protective technology, which is technology to preserve, protect and secure the ecology and environment of the future that can include conservation, restoration and regeneration of natural resources. The main elements of protective technology are enhancing sustainability, restoring fertile barren land, utilizing reeds to become arable land, and so on; c) In the political field, communication and information technology is also very necessary so that a program and ideas can run well and be known by all members of the community. The media acts as a mediator between the government and the people so that people can express their opinions and can provide input to build a better country, therefore information and communication technology also plays an active role in supporting the political development of a country [41]; d) Then the negative or negative impact is that if humans cannot use the technology wisely it will be a danger if humans become dependent on the technology. Social fragmentation itself is a division in society so that individuals become increasingly isolated and social ties also become weaker [41]. This concept is also a framework for analyzing the ways in which social actors construct meaning, identity, and institutional forms within the sociological context of globalization [42]. Indirectly, the patterns of behavior arising from the effects of the emergence of globalization have changed the behavior patterns of society which increasingly set aside social norms and change direction to digital norms.

\section{MethodS}

Creswell and Poth [43] said that "Research in investigators collects and provides data, integrates findings, and draws conclusions using qualitative and quantitative approaches or methods in a single study or inquiry program" Therefore, mixed methods can refer to the use of qualitative methods and quantitative to answer research questions in one study ". Then Julia Brannen explained a number of ways to combine quantitative and qualitative research as follows: Qualitative research helps quantitative research provide basic information about context and subject, acts as a source of hypothesis, then quantitative research and qualitative research are combined to provide a general picture. Quantitative research here includes all data and information relating to destinations and tourism object development in Bulukumba Regency, then is equipped with various sources and information about problems and their solutions in the field, then analyzes with the strength of a qualitative and SWOT analysis. Next, analyze and provide narration in general by combining quantitative data and qualitative data.

The main premise on which this method is based is to use a combination of quantitative and qualitative approaches to find primary data related to the number of tourist destinations and facilities and secondary data related to the role of technology in tourism, and the results of research that show that it is better to use two approaches than if only using one approach [44]. This methodology shows how quantitative data provides real information related to data on the number of visitors, the amount of income of the region, the number of technology users in the tourist area, then analyzed and adjusted to the results of qualitative data in the form of narratives of various information from stakeholders to obtain information about the influence of technology in tourism development in Bulukumba Regency, South Sulawesi. Then combine, analyze and equate the results of quantitative and qualitative data to draw conclusions.

\section{RESULTS}

The concept of digitalization development is intended to facilitate the achievement of objectives in an effective and efficient manner in implementing development programs, encouraging equal distribution of regional income, preserving the environment between generations, and optimizing the quality of human life. In this regard, it takes vision of balanced development, establish partnerships, and alignment between the stakeholders in tourism and other sectors. Therefore, it takes the concept of tourism planning integrated associated with other development sectors, in accordance with the concept of sustainable development (Sustainable Development), in order to develop the tourism sector in an integrated manner which requires a Tourism Development Master Plan Area (RIPPDA) Bulukumba digital-based and supported by qualified human resources for the implementation of digitization in tourism that keeps the wisdom of local content. In addition to these provisions, in preparation Bulukumba RIPP also consider legal products in Bulukumba, include; 1) The basic pattern of development Bulukumba; 2) Development Strategic Plan Bulukumba; 3) By law general plan of spatial Bulukumba.

Tourism development policy is to encourage and increase the attractiveness of a tourist area that is expected to contribute to both the local community and local government objects and can provide the benefic as much as possible for the welfare of society as a whole present and future. The development of tourism in Bulukumba implemented to encourage and try to get the results of tourism activities utilized for local welfare as much as possible and maintain and preserve the local identity that is not lost and to prevent damage to the cultural heritage owned. The development of tourism in the era of digitalization should be followed by making policies with local cultural wisdom, so that its development is always maintained, balanced and in accordance with the life of the local civilization. 


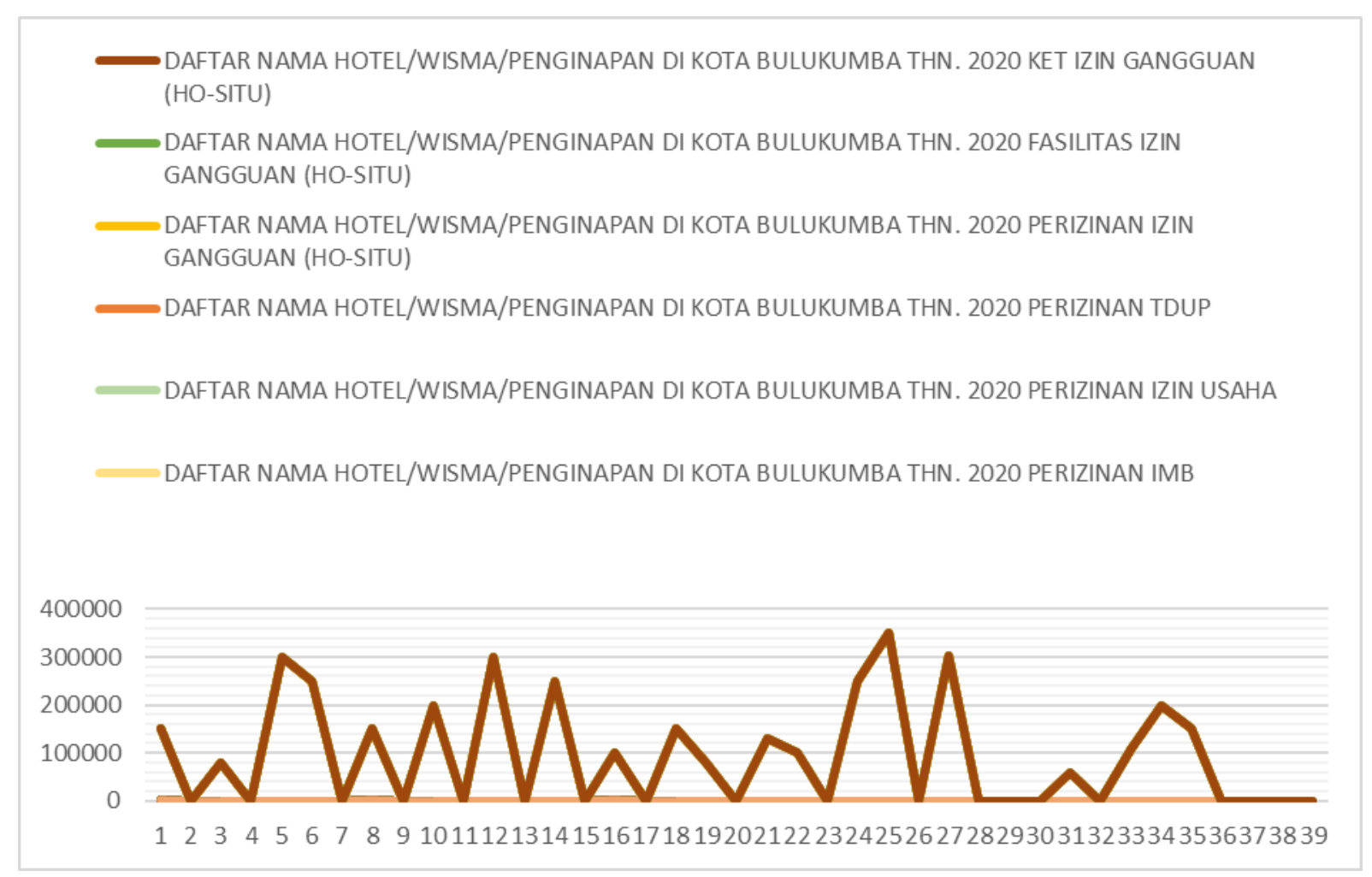

Fig. 1. Types of lodging data and issuance of the Establishmen of Bulukumba 2020.

Indirect digitalization makes it easier for state authorities to more effectively carry out studies and analyzes of tourism prospects. The prospect of a tourism industry that continues to stretch, dependently requires the capability of human resources, these challenges require systemic steps in improving the quality of human resources as tourism agents through educational institutions. Local governments must respond to this problem and carry out literacy in tourism to the wider community, because tourism has become the belle of development in Indonesia. The government has committed to making tourism as one of the economic driving sectors in 2020, local governments are expected to respond to this commitment and inventory the cultural and natural potential that can be an attractive contraction and be able to suck up tourist visits, by collaborating with various tourism industry players.

Arif Yahya is currently preparing a transformation towards tourism 4.0 in a grand strategy. The key lies in human resources, given the program determined by President Joko Widodo this year is to focus on human resources. According to Arif Yahya, there are three products for the millennial generation, namely Startup Indah Academy, Nomadic Tours, and Digital Destinations. This program provides education, knowledge sharing, guides market and business validation. and access for stakeholders, direct businesspeople, and direct consumer leaders (CEO Commitment) to make the tourism sector superior. We chose digital technology for tourism so we can shake the world, "said Tourism Minister Arief Yahya, and there are three Kemenpar products for the millennial generation namely Startup Indah Academy, Nomadic Tourism and Digital Destinations. See-Book-Pay should be considered by travelers; This Beautiful Startup Academy is to create an ecosystem so that Indonesia becomes a foreign tourist destination. This program provides education, knowledge sharing, guidance for market and business validation as well as related access to policy makers, business partners and direct buyers. Another key to success in the tourism sector cannot be separated from the commitment of the CEO (CEO Commitment) to realize the leading tourism sector.

People in the 4.0 era has been presented with the convenience of a variety of existing technologies, including the ease of getting information, facilities and the beautiful and affordable destination. 4.0 in the field of tourism industry this further enhances the digital transformation of tourism and the tourism array and digital transformation [45]. Various government programs include learning program blended learning is implemented through collaboration between start-up development of tourism and the creative industries in various tourist destinations, increase digital literacy, as well as monitoring the readiness of businesses small and medium enterprises in tourist areas [25]. The phenomenon and the government's efforts is the access to improve the quality of tourism and marketing to various countries, through digitalization literacy needs to be accommodated and this is adapted by national and local governments, including government officials Bulukumba to further enhance the advanced development of tourism industry and competitive. 
Technology is very important to assist in global development in the hope of facilitating interconnection that is beneficial for mutual benefit, making efficient performance, as well as providing a variety of accurate data-based information as an analytical material in innovative and competitive decision making. Digitalization is expected to facilitate the development and sustainable development and be a counterweight to all sectors of human life, so that life becomes more meaningful for the life of the universe. Globalization is divided into three major groups, the hyperglobalist group defines globalization as a new history of human life in which the traditional state has become irrelevant and begins to turn into business units in a global economy [46]. The concept of globalization has produced what McLuhan predicts about the global village which its constituent elements are interconnected but nevertheless, the members of this large village are not homogeneously connected [47]. For this reason, according to Wilbert Moore, modernization concept that is a comprehensive transformation of traditional or premodern society into a technological society and social organization that will follow economically and economically stable countries [48]. In Indonesia alone there are three levels of village community maturity, including in South Sulawesi, especially Bulukumba, according to Mulyadi [49] namely: 1) Communities with low maturity; 2) Society with a medium level of maturity; 3) The type of community with a high level of maturity. All of this is quite in accordance with the leadership of the government of the Regency of Bulukumba with its characteristics of wanting to do something and know how to do it. If we look further from the various theories of development theory, in it there is the term village development or what is often referred to as rural development.

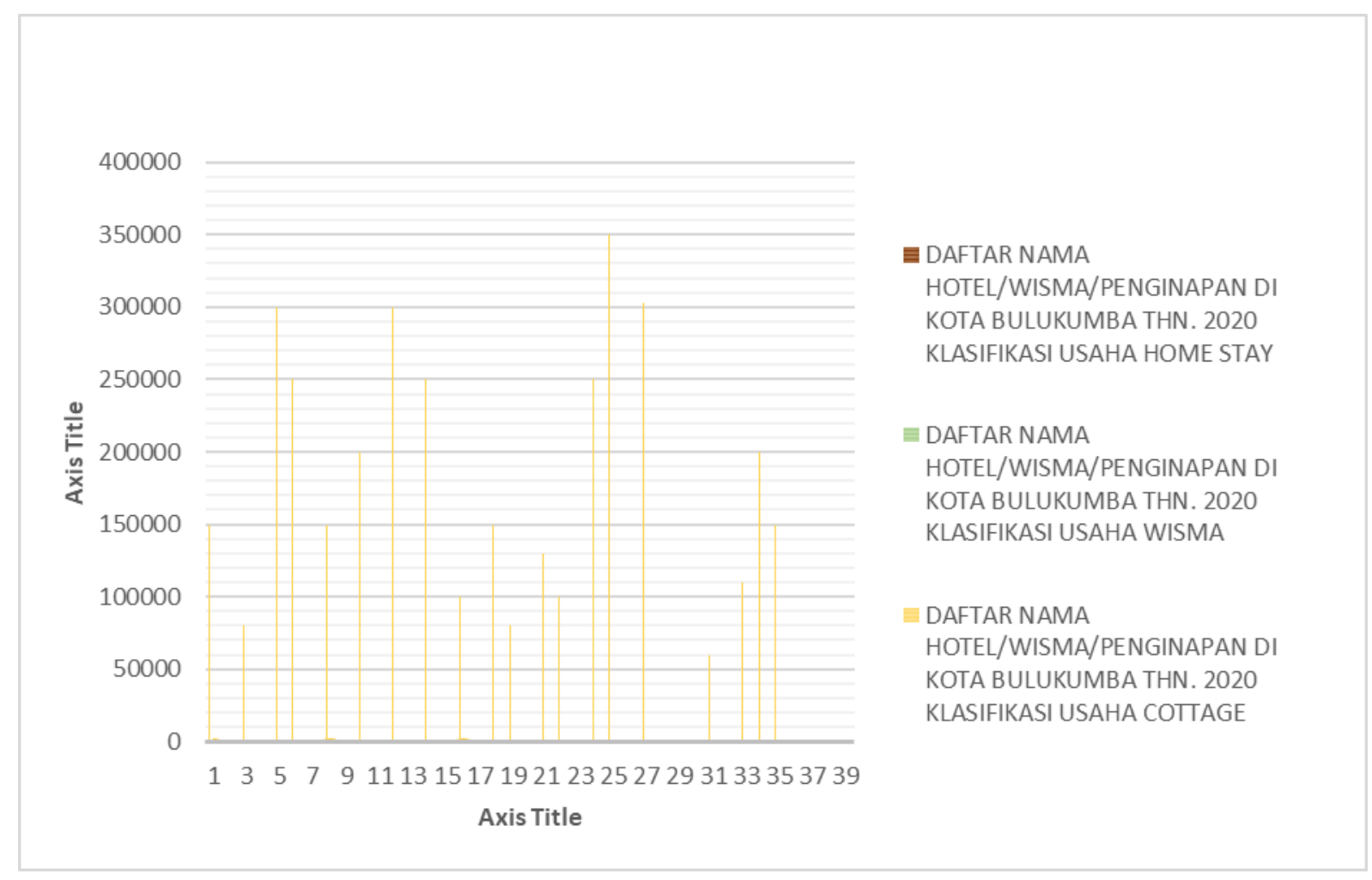

Fig. 2. Number of lodging and technology-based facilities in Bulukumba 2020.

\section{DISCUSSION}

If you look at the development of information technology, the old paradigm still tends to rely on technology transfer from developed countries, while the new paradigm tends to respect local wisdom and technology and starts to make participatory technology development efforts [50]. Likewise, by including local cargo that is still strongly held by the village such as the building of pinishi boats in Bulukumba, the main hope in rural development is the preservation of village culture or style as in the traditional life of the Kajang Bulukumba community. Furthermore, in the Village Law it is explained that the information system is intended to build transparency, community access through village websites, market access to facilitate economic movement from Village commodity products, and build an integrated system related to population data against human trafficking efforts, this can maintain and strengthening the preservation of natural balance and potential of unspoiled areas on the coast of Bira Bulukumba. Joko Widodo's Tri Sakti Nawacita Work Cabinet contains three things, namely a village that is sovereign in politics, independent in the economy, and has a cultural personality [51]. Data that is processed in an information system will not be useful if it does not have three pillars, namely people's rights 
or relevant (relevant), on time (on time), and has a high degree of accuracy [52]. Based on the APJII survey results, the majority of internet users in Indonesia live in western Indonesia, especially Java Island (Marius and Sapto; 2015). The merger of computer and telecommunication technology in this era of globalization has resulted in a revolution in information systems such as e-commerce, EDI, and so on so that it has now penetrated the physical boundaries between countries [53]. For this reason, according to Wilbert Moore, the concept of modernization is a comprehensive transformation from a traditional or pre-modern society to a technological society and social organization that will follow an economically and economically stable state [54]. Based on this population, the largest number of internet users is in West Java Province at 16.4 million, followed by East Java with 12.1 million users and Central Java with 10.7 million users [55]. This data shows that inequality causes problems in some eastern parts of Indonesia, such as the social backwardness of rural communities in development due to the difficulty of rural communities accepting a culture of modernization, difficulty accepting new technology, laziness, lack of strong motivation to change, feeling quite satisfied with fulfilling subsystem needs. , and shared provincial culture [56]. Kamaluddin [57] mentions several traditional attitudes in society that are inconsistent with the needs of development and modernization. Therefore, the village government is not an entity that is collectively united as one legal community, but as two actors facing each other. Among them, according to Alhada [58]: a) Being slow to accept changes or new things will benefit them; b) Attitude prefers to find the easiest and fastest way to bring results even if not so great.

\section{CONCLUSIONS}

The development of the tourism sector in Bulukumba Regency must utilize technology and pay attention to important aspects that can affect the growth and development of the tourism sector, namely: the tourism development policy is formulated as a guideline to facilitate the governance of tourism development. The results of this research can be a source of additional data, information and references for practitioners, government officials, especially the South Sulawesi Government in formulating policies and technology development plans to support development, as well as information to the wider community about the important role of technology in development in Indonesia.

The tourism sector in Bulukumba must utilize technology starting in the formulation of regional policies, unifying visions and missions between institutions, partnerships of the tourism industry ranks, and all stakeholders can work together in realizing a developed tourism industry. Tourism development in Bulukumba requires the support of various infrastructure, especially in managing the tourism industry digitization system. Optimizing the use of technology in supporting local governments to develop tourism sector activities that lead to the competitive advantage of sustainable tourism, especially cultural tourism in the Ammatoa Traditional Area, Pinishi Boat
Manufacturing, and Bira Beach Marine Tourism. Digitalization that is environmentally friendly and respects the basic principles of human life in rural areas is expected to be a breakthrough and solution to provide optimal services to the wider community in sustainable development.

\section{REFERENCES}

[1] N. Nasution, Manajemen Mutu Terpadu. Bogor: Ghalia Indonesia, 2015.

[2] Bambang, Ministry of PPN/Bappenas, Kementerian PPN/Bappenas. Jakarta: Indonesia, 2020.

[3] C.K. Dimitriou, "The Quest for a Practical Approach to Morality and the Tourism Industry,” J. Hosp. Tour. Manag., vol. 31, pp. 45-51, 2017.

[4] S.-T. Liu, "Comparing the Perspectives of Municipal Tourism Departments and Cultural Departments on Urban Cultural-Tourism Development,” J. Destin. Mark. Manag., vol. 16, p. 100432, 2020.

[5] J. Macbeth, "Towards an Ethics Platform for Tourism," Ann. Tour. Res., vol. 32, no. 4, pp. 962-984, 2005.

[6] M. Mkono and A. Holder, "The Future of Animals in Tourism Recreation: Social Media as Spaces of Collective Moral Reflexivity," Tour. Manag. Perspect., vol. 29, pp. 1-8, 2019.

[7] R. Saner, L. Yiu, and M. Filadoro, "Tourism Development in Least Developed Countries: Challenges and Opportunities," in Sustainable Tourism: Breakthroughs in Research and Practice, IGI Global, 2019, pp. 94-120.

[8] M. Labiran, "Analisis Penerimaan Daerah Dari Sektor Pariwisata Di Kabupaten Tana Toraja Dan Faktor-Faktor Yang Mempengaruhinya,' Fak. Ekon. Dan Binis. Univ. Hasanuddin Makassar, 2013.

[9] K.A. Nurfadilah, "Strategi Pengembangan Pariwisata Pantai Pangandaran (Studi Kasus Di Kabupaten Pangandaran)," 2017

[10] Y. Paris, "Pengaruh Pelayanan Bidang Penerbitan Sertifikat Tanah Terhadap Kepuasan Masyarakat Pada Kantor Badan Pertanahan Nasional Kota Makassar," J. Ilm. Ilmu Adm. Publik, vol. 4, no. 1, pp. 65-83, 2016.

[11] S. Sofyan, A. Siraj, and M. Mardyawati, "Workforce Managemen Evaluation at Adinda Parinring Kindergarten Makassar," J. Ilm. Ilmu Adm. Publik, vol. 9, no. 1, pp. 71-76, 2019.

[12] T. Prasodjo, "Pengembangan Pariwisata Budaya Dalam Perspektif Pelayanan Publik,” J. Off., vol. 3, no. 1, pp. 7-12, 2017.

[13] W.J. Winowatan, "Persepsi Stakeholder Terhadap Kurikulum Berbasis Kompetensi Politeknik Pariwisata Makassar (Studi Pada Industri Perhotelan Kota Makassar)," J. Ad'ministrare, vol. 5, no. 2, pp. 123 128, 2019.

[14] P.S. Prasetyo, K.W. Wicaksono, T.S. Herwanto, G. Mulyadi, and R.A. Malik, "Proses Dan Implikasi Innovative Governance Terhadap Kualitas Pelayanan Publik Di Desa Sukalaksana Kecamatan Samarang Kabupaten Garut,” 2016.

[15] W. van Acker and G. Bouckaert, "What Makes Public Sector Innovations Survive? An Exploratory Study of the Influence of Feedback, Accountability and Learning," Int. Rev. Adm. Sci., vol. 84, no. 2, pp. 249-268, 2018.

[16] I. Nurrohmah, M.A.A. Dewi, and N. Sahadi, "Measuring the EGovernment Maturity in Indonesia Using the Ranking of e-Government of Indonesia (PeGI),” Am. Sci. Res. J. Eng. Technol. Sci., vol. 32, no. 1, pp. 49-63, 2017.

[17] B.S.D. Oetomo, "Kesiapan Pemerintah Dalam Mengembangkan Sistem E-Government," J. Eksplor. Karya Sist. Inf. dan Sains, vol. 9, no. 2, 2016.

[18] S. Chakrabarti and A.D. Tatavarthy, "The Geography of Medical Travel in India: Differences across States, and the Urban-Rural Divide," Appl. Geogr., vol. 107, pp. 12-25, 2019. 
[19] L. Cheng, C. Chen, and C. Xiu, "Excess Kindergarten Travel in Changchun, Northeast China: A Measure of Residence-Kindergarten Spatial Mismatch,” J. Transp. Geogr., vol. 60, pp. 208-216, 2017.

[20] L. Cheng, X. Chen, S. Yang, Z. Cao, J. De Vos, and F. Witlox, "Active Travel for Active Ageing in China: The Role of Built Environment," J. Transp. Geogr., vol. 76, pp. 142-152, 2019.

[21] D.B.E. Dharmowijoyo, Y.O. Susilo, and A. Karlström, "Analysing the Complexity of Day-to-Day Individual Activity-Travel Patterns Using a Multidimensional Sequence Alignment Model: A Case Study in the Bandung Metropolitan Area, Indonesia,” J. Transp. Geogr., vol. 64, pp. $1-12,2017$.

[22] J.H. Lee, A.W. Davis, and K.G. Goulias, "Triggers of Behavioral Change: Longitudinal Analysis of Travel Behavior, Household Composition and Spatial Characteristics of the Residence," J. choice Model., vol. 24, pp. 4-21, 2017.

[23] L. Li, K.Y. Lee, and S.-B. Yang, "Exploring the Effect of Heuristic Factors on the Popularity of User-Curated "Best Places to Visit'Recommendations in an Online Travel Community," Inf. Process. Manag., vol. 56, no. 4, pp. 1391-1408, 2019.

[24] A. Neven, D. Janssens, G. Wets, K. Beirlant, B. Willekens, P. Van Asch, P. Vanlimbergen, and P. Feys, "Influence of Functioning and Contextual Factors on Activity-Related Travel Behaviour in Multiple Sclerosis," J. Transp. Heal., vol. 11, pp. 100-109, 2018.

[25] A.C. Nur and M. Guntur, Analisis Kebijakan Publik. Makassar: Publisher UNM, 2019

[26] A.C. Nur, R. Niswaty, and H. Akib, "Development Of Local Potential Enterpreneurial Based Tourism Destination In East Beach South Sulawesi Indonesia."

[27] F. Said, H. Akib, R. Salam, and A. Baharuddin, "An Analysis of Tourism Visit Trend," 2017

[28] Y. Samad, M.A. Muhammad Salim, and H. Akib, "The Functions of Language in Realizing the Indonesian Culinary on the Official Tourism Website of Indonesia: A Tourism Discourse Perspective," Funct. Lang. Realiz. Indones. Culin. Off. Tour. Website Indones. A Tour. Discourse Perspect. (October 31, 2018). Ewha J. Soc. Sci. Forthcoming, IOSR J. Humanit. Soc. Sci. (I, vol. 23, no. 10, pp. 7-15, 2018.

[29] S. Annis, "Evolving Connectedness among Environmental Groups and Grassroots Organizations in Protected Areas of Central America," World Dev., vol. 20, no. 4, pp. 587-595, 1992.

[30] G. Saxena and B. Ilbery, "Integrated Rural Tourism a Border Case Study,” Ann. Tour. Res., vol. 35, no. 1, pp. 233-254, 2008

[31] G. World, Trade in a globalizing world. 2008.

[32] D. Sterchele, "Memorable Tourism Experiences and Their Consequences: An Interaction Ritual (IR) Theory Approach," Ann. Tour. Res., vol. 81, p. 102847, 2020.

[33] S. Darsoprajitno, "Genangan Dan Kekeringan, Ekologi Dan Pembangunan, Sumberdaya Air Dalam Konteks Pengelolaan Daerah Tangkapan Air," Bandung Pus. Penelit. Sumber Daya Alam dan Lingkungan-Lembaga Penelit. Univ. Padjadjaran, vol. 6, pp. 18-29, 2002.

[34] L. Dwyer, P. Forsyth, and W. Dwyer, Tourism economics and policy. Channel View Publications, 2020.

[35] A. Toffler and T. Alvin, The third wave, vol. 484. Bantam books New York, 1980
[36] S. Aghaei, M.A. Nematbakhsh, and H.K. Farsani, "Evolution of the World Wide Web: From WEB 1.0 TO WEB 4.0," Int. J. Web Semant. Technol., vol. 3, no. 1, pp. 1-10, 2012.

[37] M.R. Solanki and A. Dongaonkar, "A Journey of Human Comfort: Web 1.0 to Web 4.0," Int. J. Res. Sci. Innov., vol. 3, no. 9, pp. 124-134, 2016.

[38] T. Wahyono, "Sistem Informasi," Yogyakarta Graha Ilmu, 2004.

[39] M. Anastasia, "Dampak Positif Dan Negatif Teknologi Komunikasi Dan Informasi," 2014.

[40] Djojohadikusumo, Indonesia Toword The Year 2020. 1975

[41] H. Hartanto, "Piala Dunia 2014: Cermin Keberhasilan Diplomasi Brazil Serta Dampaknya Bagi Perkembangan Ekonomi," J. Tapis J. Teropong Aspir. Polit. Islam, vol. 12, no. 1, pp. 1-18, 2016.

[42] E. Pamungkas, "Analisis Faktor-Faktor Yang Mempengaruhi Struktur Modal Pada Perusahaan Manufaktur Go Public Yang Terdaftar Di Bursa Efek Indonesia (BEI).” Universitas Muhammadiyah Purwokerto, 2015.

[43] J.W. Creswell and C.N. Poth, Qualitative inquiry and research design: Choosing among five approaches. Sage publications, 2016.

[44] J.W. Creswell, "Research Design: Qualitative Approach, Quantitative and Mixed," Yogyakarta Student Libr., 2013.

[45] F. Said, A. Wahidiyat, D.D. Andayani, H. Harifuddin, and R. Salam, "Development of Travel Attractions Through the Design of Google SketchUp Based Coastal Tourist Map (Pengembangan Daya Tarik Wisata Melalui Perancangan Peta Wisata Pantai Berbasis Google SketchUp)," Pekommas, vol. 2, no. 2, 2017.

[46] B. Winarno, "Kebijakan Publik: Teori Dan Proses," Yogyakarta Media Press., 2007.

[47] B.J. Walkosz, T. Jolls, and M.A. Sund, "Global/Local: Media Literacy for the Global Village," in Paper Submitted for International Media Literacy Research Forum Inaugural Meeting, Ofcom, London, 2008, pp. $14-16$.

[48] B. Winarno, "Kebijakan Publik: Teori Dan Proses, Yogyakarta," Med Press, 2007.

[49] Mulyadi, Akuntansi Biaya. Yogyakarta: Yogyakarta: STIE YPKPN, 2009.

[50] S. Eko, T.I. Khasanah, D. Widuri, S. Handayani, and N. Handayani, "Desa Membangun Indonesia," FPPD. Yogyakarta, 2014.

[51] M. Mardiana and K. Kurniawan, "Improving Students'reading Comprehension By Using Media At The Grade X3 Of Sma Negeri I Tambang-Kampar," Lect. J. Pendidik., vol. 6, no. 2, pp. 1-21, 2015.

[52] H.M. Jogiyanto, "Sistem Teknologi Informasi," Andi. Yogyakarta 2005.

[53] J. Simarmata, "Pengenalan Teknologi Komputer Dan Informasi," 2006.

[54] A.A. Long and D.N. Sedley, The Hellenistic Philosophers: Volume 2, Greek and Latin Texts with Notes and Bibliography. Cambridge University Press, 1987.

[55] P. Marius and S. Anggoro, "Profil Pengguna Internet Indonesia 2014," APJII, Jakarta, 2015.

[56] A.J. Mahardhani, "Strategi Pembangunan Desa." Ponorogo: Unmuh Ponorogo Press, 2014

[57] K. Kallo, "Strategi Pemberitaan Kriminal Radar Bone." Universitas Islam Negeri Alauddin Makassar, 2020.

[58] M. Alhada, "Pencemaran Air Sungai Di Indonesia," Ilmu Sos. dan Polit. Airlangga, 2012. 